\title{
Research on the Consumer Rights Protection in Online Shopping: a Empirical Analysis based on Consumer Credit Law
}

\author{
Shuangjun $\mathrm{Xu}$ \\ School of Management Engineering, Suzhou University, Suzhou city, Anhui \\ province, 234000, China \\ *Corresponding author: Shuangjun Xu (xsj0410@163.com)
}

\begin{abstract}
With the development of the Internet economy, most people begin to accept online shopping. From the perspective of information economics, consumer credit market is particularly important. The protection of credit consumer rights can improve the shopping satisfaction, and thus to overcome the negative impact of the information asymmetry and the moral hazard. In this paper, we make empirical analysis about the consumer rights protection in online shopping, and test the impact of shopping satisfaction on customer relationship quality. The result shows that consumer rights protection will improve the Customer satisfaction and trust, and conduce to improving the quality of customer relationships. Therefore, construct and improve the legal system of consumer credit law is particularly important.
\end{abstract}

Keywords: Consumer rights protection, Online shopping, Credit law, Empirical analysis

\section{Introduction}

Regardless of the experience of developed countries shows that the theory of consumer economics, when a country's economic development to a certain stage, it is bound to require economic development mode from investment, exports to consumer led. At the same time, the economic development will also cause the consumption structure from the life necessities to the consumer durable goods, the high price of consumer durable goods to stimulate domestic demand must rely on the support of consumer credit. The conflicts of interest among the main body of the consumer credit market determine the necessity of protecting the weak consumer. Not only so, credit consumer protection is an important tool to reduce the risk of financial market system. Visible, the significance of the credit system of protection of consumer rights, not only is the protection of the interests of the individual micro society, but involves the financial market of safety and the economic development mode transformation of success or failure. This also confirms the Kos said, the market failure is there, but the key is to solve the system arrangement, the source of economic growth in the history of the effective rate of institutional arrangements.

In the media environment, the lack of face-to-face interaction with customers, businesses are difficult to control the process of service, customers can not see the service staff, also can not contact with the commodity, easy to form a sense of bias and complaints or dissatisfaction, may greatly improve the service failure. Service failure and customer dissatisfaction continues to increase, so that the enterprise has to take service recovery measures to reduce the negative impact on consumers and businesses due to the failure of service. The way of economic development has become the urgent demand and basic foothold of the economic development of our country, the realization of the transformation depends on 
the consumption demand, and the consumption structure of our country is mainly based on the life necessities. However, consumer rights in credit consumption have been damaged, which seriously hit the enthusiasm of the credit consumer credit, which has restricted the domestic demand. Not only so, the financial crisis with the brutal facts tell us that the protection of the credit consumer rights and the entire financial market system of the causal relationship between the systemic risk not only stay in theory. When the damage to the credit consumer rights of consumer credit products, there is a large area, it is bound to lead to a high rate of consumer defaults and consumer confidence in the market, at the moment, the financial market's security and stability at risk. Can be seen, the demand for domestic economic development and foreign financial crisis will be the same direction of the system needs to point to the same direction: the protection of credit consumer rights. Accordingly, the credit protection of consumers' rights is of great significance to study, not only involves the credit consumer interests, but a matter of the stability of the financial market, and in China at the present stage of the transition of the mode of economic development and the future of the national economy development.

\section{Literature Review}

\subsection{Consumer Rights Protection}

The legitimacy analysis of credit consumer rights protection is the premise of the construction of the protection system, and it is also the part of the existing research. Gong Rui (2002) from the main fairness and social benefits of two angles to demonstrate the legitimacy of the protection of credit consumer rights, on the one hand, the consumer credit market, the format contract is developed by the credit granting, serious limitations and even deprived of the interests of consumers, the right to trade balance of rights and obligations, should protect the credit consumer rights amendment imbalance. On the other hand, the level of consumer protection has a direct impact on the social effect of the consumer credit economy. Because of the positive and negative two social effects of credit consumption, only to provide a good legal environment for the credit consumers, can improve the quality of life, and thus form a healthy development, and promote social stability and stable operation. Otherwise, the right to protect the credit consumers, often easy to lose the ability to repay, causing many social problems. Chen Liang (2005) chose the other three dimensions to demonstrate the legitimacy of credit consumers, and its one, from the perspective of law, credit is a right of the debtor, and the right to be protected; second, from the economic point of view, credit consumer protection is the inevitable choice, because consumer credit can ease the pressure on consumer purchasing power, expand business areas of financial institutions and promote the business of sales and stimulate consumption, expanding domestic demand. Third, from the credit consumer rights belong to the people's pursuit of happiness, which is part of human rights. Li Yanni (2006) will protect the theoretical source of credit consumer rights to the two major players in the market position of credit consumer credit and credit, because the consumer credit transactions and complexity, consumers in information collection and control is significantly less than the credit granted, and the organization level, economic strength is also difficult to match, from a fair point of view, in a weak credit consumers should be inclined to protect. 


\subsection{Consumer Credit Law}

Since the rise of housing credit in China in 1997, China's legal theory has begun to focus on the western developed countries in the consumer credit legal system; there are some of the United States or the United Kingdom credit consumption system to introduce the analysis of the article. And the first system of system introduction is consumer credit law research, the book to the United States, Britain, Japan, the consumer credit legal system as the main research object. The new consumer credit law added to France, the European Union and Australia consumer credit legal system is introduced. Because these countries' consumer credit law has the nature of consumer protection law, so the developed countries of credit consumers have the right type of basic. Not only that, the EU credit consumer protection system research (2010) also specifically introduced the European Union in the analysis of the European credit consumer protection system, the adoption of the entire EU Member States to protect the credit consumer protection system. For later research further provides the basis for the conditions, in addition, brigade, and American scholars in the introduction of foreign consumer credit system, credit system of protection of consumer rights has become an integral part of, such as the "Japanese consumer credit system and system" and the American consumer credit system, although the two books are not specialized legal writings, but with special chapters outline the Japan, the United States consumer credit legal system, but also through the narration of the host country consumer credit market conditions, indirectly describes the generation of credit consumer rights and historical conditions and background. With the development of the credit market, foreign research focus began to shift to the protection system, such as the British government realized that the original regulatory system has been difficult to meet market needs, based on the twenty-first Century British consumer credit market the white paper, the credit market is the lack of information disclosure before signing, and other issues, the need to amend the advertising law, strengthen information disclosure, based on the establishment of a transparent market system, and through a strong credit business license system, to eliminate the credit limit of credit consumer protection and other measures to establish a more equitable regulatory framework.

\subsection{Service Recovery}

The term "service recovery" was first introduced in the field of marketing by the British Airways in early 1980s, and it was considered as a series of actions or responses to the failure of the enterprise to take a series of actions or responses, the purpose is to obtain and maintain customer satisfaction and loyalty by taking a certain service recovery measures. Domestic and foreign scholars have different definitions of service recovery, which is representative of the following: Zhang thinks that service recovery can be considered as the process of customer complaint. Chin considers that service recovery is a process of making the product or service provider for the customer's satisfaction with the lack or failure of the product or service provided by the enterprise. Wang considers that service recovery should be considered as a kind of management process, which needs to be solved by the discovery of service failure, and to analyze the causes of service failures, and to evaluate the negative effects caused by the service failures on the basis of quantitative analysis. And the general level of service recovery should also include the prevention measures and enterprise internal service recovery and other contents of the enterprise in order to prevent the occurrence of service failure. li believes that service recovery should be considered as a service provider to the 
customer's complaint or remedy, and the objective is to obtain the customer satisfaction and customer loyalty. After research and discussion, and on the basis of the original research, the role and status of service recovery should be redefined. He will serve as a service to provide enterprises with all the actions taken to cope with the failure of service, the purpose is to change the customer because of the occurrence of service failure. Scholars Wei Fuxiang believes that the enterprise for the service failure occurred in the immediate and proactive response that service recovery, the purpose is to expect to adopt a certain remedial measures to the extent of the negative impact of service failure on consumers to a minimum. Chen Zhongwei and Dong Xiaobo think that the service recovery is a series of activities which can be caused by the loss of customers, and to establish the continuous customer relationship and continuous improvement.

The quality of service recovery is the first source to study the quality of service, more is the service recovery quality as a measure of the quality of service. The effect of service recovery is considered to be the quality of the two service enterprises. When service failure occurs, the enterprise in order to restore the negative impact caused by the failure of service to consumers, will take certain remedial measures, and the effect of remedial measures is undoubtedly the key.

\section{Legal System of Consumer Rights Protection}

\subsection{Credit Consumer Rights}

Through the legal recognition and protection of the rights of the consumer credit become the common choice of economy and finance in developed countries, and in the construction of the system exist many common points, specifically, credit consumer protection legal framework mainly includes the contents of three dimensions: one is through the design of the legislation and declared the credit consumers enjoy all kinds of real rights and the credit grantor of the corresponding obligations; the second is to develop credit consumer rights protection supervisory system, give full play to regulators of credit consumer rights protection function; three, establish consumer credit right relief system, to implement the protection of the rights. A lot of developed countries have worked out the consumer credit laws which are aimed at protecting the rights of credit consumers and the core. We especially focus on the United States of the Consumer Protection Act, the United Kingdom's consumer credit law, Japan's loan payment industry regulations and other laws and regulations, and the consumer credit law, the above legislation clearly established credit consumer rights, including the following five categories:

1) Right to know: for the credit consumer market information asymmetry is more prominent, the developed countries have to develop the relevant laws and regulations to provide credit to the information disclosure obligations, to protect the right to know the credit consumers, so as to make up for the lack of autonomy of credit consumers. Foreign legislation on the protection of credit consumer's right to know in credit consumption mainly depends on two aspects of the information disclosure.

2) Consumption credit right: the right of consumer credit is the right of the consumer to obtain the trust and the evaluation of the use, maintenance and maintenance in the society. Foreign typical legislation to protect the credit consumer's consumption credit is mainly from the following two aspects, one is 
the credit consumer's rights to maintain their own credit (credit records), the two is the use of their own credit to obtain the right to consume credit.

3) Regret right: in a particular transaction environment, facing the professional smart credit grantor, consumers are often susceptible to persuasion or because of the unclear understanding of the consumption of complex targets, and under the serious asymmetry of wrong to buy their own do not need or cannot afford the goods. And the above is not enough to constitute fraud, coercion, take person's dangerous form, thus unable to start the right of Rescission in civil law, in accordance with the principles of civil law "stick to the contract", but require consumer credit to perform their obviously unfair contract.

4) Extended defense right: in the modern consumer credit, credit granting (financial institution) and vendors are closely linked, the two party to provide consumers with goods, a party to provide funds to the credit granted by the seller - credit consumers as a structural form of joint credit occupy the dominant position of consumer credit. However, according to the principle of relativity of contract, the contract of sale and credit are independent, which leads to the opposite party of the contract, so that the seller or the credit can be used to repay the loan or the purchase of goods or services. After many years of game, the developed countries have made a breakthrough in the relative principle of the contract in the legislation. The extension of defense right here is the right of defense of the other related contract.

5) Information security right: CGAP(Consultative Group to Assist the Poor) launched the "financial availability report 2010", the 142 economies in the investigation, $80 \%$ in their respective legislation to protect consumer privacy clause. The privacy right in the report is contained in the right of information security. Credit consumer information security is the right of credit consumers in their financial information and related personal information, and is not subject to the security of the illegal interference of others. The title of this right is not entirely consistent, but the content of the provisions of the basic focus on the protection of the content and the exclusion of the two aspects.

\subsection{Credit Consumer Rights Issues Highlighted}

Since 1990s, China has formulated a series of policies and regulations for the development of consumer credit, and "Buy" is generally accepted by the consumer, credit cards, installment and other consumer credit has become a fairly common consumer, consumer credit has entered an unprecedented period of rapid development. Consumer credit rapid development at the same time, the credit consumer rights is seriously damaged, according to the Shanghai Banking Bureau of the latest data show that in 2014 consumer and financial institutions service disputes complaints accounted for $83 \%$ of the total, and mainly in the credit card, bank charges and the physical aspects of financial products. Among them, the credit card has become the most concentrated areas of complaints. According to the popularity of the highest rate of credit card consumption credit, through the investigation of the four major state-owned banks, has been appraised as "the most popular credit card" China Merchants Bank credit card receipt agreement and on the bill, we found that the credit consumer's right to know the infraction: first, the five major credit card issuing bank credit card agreement, almost all contain to amend the Constitution without the direct credit card 
consumer notice provisions, such as the Construction Bank: this agreement is based on the Chinese Construction Bank long quasi credit card charter amendment, fees or standard changes, the interest rate adjustment, the approval of the financial supervision department and a announcement is effective, without prior notice, the revised terms of binding by both parties, have. It is not difficult to see that China's credit card issuing bank to amend the credit card regulations and agreements, without credit consumer consent, but only through the bank's official website announced on the presumption of credit consumer knowledge, and not directly inform the consumer of the consequences of the credit, it is clear that even the basic right to know are not guaranteed.

\section{Empirical Analysis}

\subsection{Questionnaire Design}

Based on systematic review of previous literatures, this paper puts forward the relationship between customer and merchant's relationship quality, service recovery quality and customer's emotion and purchase intention in the context of network shopping environment, and constructs a model of the relationship between service recovery quality and purchase intention. Service recovery is very important to consumer sentiment. The effective service recovery measures can make up for the emotional harm caused by service failure to a certain extent, thereby reducing the negative influence of the consumer's negative emotion definition and subsequent behavior. The change of consumer sentiment has a significant impact on the psychological and behavioral responses, and its influence may exceed the service failure itself. The relationship quality is defined as the relationship between the two sides. As the customer relationship quality is a multi dimension construction, this study combined with previous scholar's research, from customer satisfaction and trust in two dimensions to measure customer relationship quality. Based on the actual situation of this study, six questions are proposed to measure customer satisfaction and trust in two dimensions, as shown in Table 1.

Table 1. Quality Measurement of Network Customer Relationship

\begin{tabular}{|c|c|}
\hline Serial no. & Content \\
\hline Q1 & I think it's right to choose to shop in this shop. \\
\hline Q2 & Make me feel happy in the shop. \\
\hline Q3 & I am satisfied with the service provided by the shop. \\
\hline Q4 & I believe that the shop is open to customers \\
\hline Q5 & I believe that the shop will pay attention to my needs and interests \\
\hline Q6 & I believe that the shop is worthy of trust \\
\hline
\end{tabular}

In order to guarantee the wide and representative sample object, this research is designed by the professional questionnaire, and the generated web pages are distributed in the forum. The questionnaire time is from June 1 to December 31, 2014, a total of 450 copies of the questionnaire. In order to obtain more accurate and valid data, this study is to set up the rules in the questionnaire. After screening the questionnaire, 402 valid questionnaires were obtained, which were used for the following hypotheses. At the same time, the collected valid questionnaires were greater than the question items in the questionnaire 1 time, consistent with the use of structural equation model to analyze the sample size requirements. By means of SPSS statistical analysis software, the demographic characteristics, the network shopping 
experience and the online shopping frequency are analyzed. The results are shown in the table:

Table 2. Basic Information of the Sample

\begin{tabular}{|c|c|c|c|}
\hline Project & Category & Number & Percent \\
\hline \multirow{2}{*}{ Gender } & Male & 170 & $42.29 \%$ \\
\cline { 2 - 4 } & Female & 232 & $57.71 \%$ \\
\hline \multirow{4}{*}{ Age } & Under 18 & 2 & 0.5 \\
\cline { 2 - 4 } & $18-24$ year & 170 & 42.29 \\
\cline { 2 - 4 } & $24-35$ year & 226 & 56.22 \\
\cline { 2 - 4 } & Over 35 Over & 4 & 1.0 \\
\hline \multirow{3}{*}{ Education level } & Junior College & 14 & 3.48 \\
\cline { 2 - 4 } & Undergraduate & 226 & 56.22 \\
\cline { 2 - 4 } & Graduate student & 162 & 40.3 \\
\hline \multirow{2}{*}{$\begin{array}{c}\text { Online shopping } \\
\text { experience }\end{array}$} & Within 1 year & 56 & 13.9 \\
\cline { 2 - 4 } & 1-3 years & 220 & 34.7 \\
\cline { 2 - 4 } & Over 3 years & 126 & 31.4 \\
\hline
\end{tabular}

\subsection{Reliability Test}

Reliability is the credibility of the questionnaire, the stability and consistency of the measurement results, the measurement results are the focus, the analysis is to examine whether a set of evaluation items measure the same concept, whether these projects have a high degree of internal consistency. The higher the consistency is, the more significant the evaluation project is, the higher the credibility of the evaluation results is. Questionnaire in this study the scale of Likert scale, the table to table items were tired Calais measurement conception of a dimension of the index. Therefore, it is necessary the internal consistency of the measurement. Researchers in the most commonly used reliability measure Cronbach's $\alpha$ coefficient of. Generally, if Cronbach's $\alpha$ coefficient is less than 0.6 , reliability is not ideal; between 0.6 and 0.7 , the reliability is good; to 0.7 , with good reliability. If the reliability is very low, then delete the measurement items, so as to ensure the credibility of the questionnaire. Customer relationship quality and its dimensions of scale s' numerical system as shown in table 3. Among them, 0.974 total customer relationship quality table of Cronbach's $\alpha$ value; customer satisfaction coefficient 0.918 , trust structure surface coefficient of 0.921 , more than the minimum acceptable level. At the same time, the sub item to total correlation coefficient minimum 0.806, greater than the acceptable level, delete any items, Cronbach's $\alpha$ coefficient were no significantly increased. The analysis results of each index variable, visible customer relationship quality scale internal consistency, high reliability.

Table 3. Reliability Analysis of Customer Relationship Quality

\begin{tabular}{|c|c|c|c|}
\hline Index & $\begin{array}{c}\text { Correlation } \\
\text { coefficient }\end{array}$ & $\begin{array}{c}\text { Cronbach's } \alpha \text { if item } \\
\text { deleted }\end{array}$ & Cronbach's $\alpha$ \\
\hline $\begin{array}{c}\text { Customer relationship } \\
\text { quality }\end{array}$ & -- & -- & 0.947 \\
\hline Customer satisfaction & -- & -- & 0.918 \\
\hline Q1 & 0.806 & 0.906 & -- \\
\hline Q2 & 0.883 & 0.824 & -- \\
\hline Q3 & 0.816 & 0.849 & -- \\
\hline
\end{tabular}




\begin{tabular}{|c|c|c|c|}
\hline Trust & -- & -- & \\
\hline Q4 & 0.819 & 0.902 & -- \\
\hline Q5 & 0.860 & 0.862 & -- \\
\hline Q6 & 0.841 & 0.885 & -- \\
\hline
\end{tabular}

\subsection{Validity Test}

Validity refers to the validity of the measurement questionnaire, which is to verify the accuracy of measurement tools and means, and to reflect the difference between the measured value and the true value. The most commonly used validity tests include two aspects of content validity and construct validity. Content validity refers to the content of the test items involved in the content of the required measurement range of the level of measurement, is the content of the measurement content of the content of the subjective evaluation of the pros and cons. The high content validity must have two basic conditions: the content of the required measurement must be clearly defined, and the test items should be representative of the scope of the definition. In the course of the study, the questionnaire of the scale of the formation of the domestic and foreign scholars have been fully referred to the research results, on the basis of summarizing the existing maturity scale, and with the teacher, the students exchange to complete this study design. The questionnaire survey results show that the questionnaire has good reliability and can be considered as a high content validity of the questionnaire. Construct validity was used to evaluate the structure and characteristics of the scale, and it is usually used to verify the validity of the model. This study will be used in the AMOS software operation. The first order confirmatory factor analysis of the quality of customer relationship is shown in Table 4.

Table 4. Fitting Index

\begin{tabular}{|c|c|c|c|c|c|c|c|c|}
\hline Index & $\chi 2 / \mathrm{df}$ & GFI & AGFI & RMSEA & NFI & NNFI & PNFI & PGFI \\
\hline Evaluation criteria & $1 \sim 3$ & $>0.9$ & $>0.9$ & $<0.08$ & $>0.9$ & $>0.9$ & $>0.5$ & $>0.5$ \\
\hline Fitting results & 1.631 & 0.984 & 0.943 & 0.056 & 0.992 & 0.997 & 0.516 & 0.560 \\
\hline
\end{tabular}

The customer relationship quality is analyzed by the first order confirmatory factor analysis. The results are shown in Table 5. It is obvious that the factor load of customer satisfaction and trust in the two component table of customer relationship quality is 0.857 , which is higher than 0.5 , and the $\mathrm{T}$ value is higher than 1.96 , which indicates that the two component of the customer relationship has a high construct validity.

Table 5. Confirmatory Factor Analysis

\begin{tabular}{|c|c|c|c|}
\hline \multirow{2}{*}{ Variable } & Item & $\begin{array}{c}\text { Standardized factor } \\
\text { loading }\end{array}$ & T value \\
\hline \multirow{3}{*}{$\begin{array}{c}\text { Variable } \\
\text { Customer satisfaction }\end{array}$} & Q1 & 0.857 & -- \\
\cline { 2 - 4 } & Q2 & 0.959 & 18.601 \\
\cline { 2 - 4 } & Q3 & 0.863 & 15.987 \\
\cline { 2 - 4 } Trust & Q4 & 0.871 & -- \\
\cline { 2 - 4 } & Q5 & 0.905 & 18.356 \\
\cline { 2 - 4 } & Q6 & 0.901 & 17.823 \\
\hline
\end{tabular}




\section{Conclusion}

Credit consumer rights is a new type of right to enter the era of consumer goods, the legal system of the right to pay attention and protection, but also reflects the progress of a country's legal civilization. Credit consumption refers to the consumption behavior of consumers through the support of consumer credit. There are many differences between credit consumption and traditional consumption, which has five special attributes. One is that the credit is the dominant in the transaction, the two is the credit consumption, the three is the credit consumption and the complexity of the legal structure; five is the form of the contract of credit consumption. It is based on the above characteristics, credit consumers than the average consumer in the transaction status is weaker; the protection of their rights is more intense. The protection of credit consumer rights should be demonstrated in three aspects: economics, sociology and law. From the perspective of consumer economics, through the analysis of the development of credit consumer rights protection system in the United States, Australia, Japan and other developed countries in the process of economic development, credit consumer protection system to help the economic development mode transformation. From the perspective of institutional economics, the existing civil law and consumer protection law, credit consumers are required to pay high transaction costs.

\subsection{Strengthen Credit Consumer Legislation}

From the point of view of the nature of consumer credit, whether it is sales credit or credit, credit is used to achieve the same purpose - personal or household consumption, and with the development of consumer credit, sales credit is no longer rely on vendors to provide credit, operators in installment sales of goods or services, is also by the funds and professional advantage of the bank credit to credit consumers, and then by consumers to repay the price. Visible, banks and other financial institutions is the consumer's credit supply, consumer credit of the two kinds of circumstances is only the difference between the bank to provide indirect loans and direct loans. In this process, the consumer protection of the rights is essentially the same; there is no need to separate legislation.

\subsection{Protect the Consumer's Right to Know}

The free market economic model assumes that consumers can obtain useful information about the choice of their own, and that the cost and benefit of these choices, and then consumers can make the choice of their own interests. However, the reality of the credit market and the assumption of a sharp contrast, which affects the judgment and choice of credit consumers, often make it into a predicament, this situation makes it necessary to protect the system of consumer right to know. Modern social advertising has become one of the important ways to obtain information of credit consumers. Therefore, the design of the right to know should mainly from two aspects of information disclosure and trading conditions.

\subsection{The Right to Fair Credit}

Consumer credit is in the era of durable consumer goods, to protect the basic living conditions, and to promote the development and self perfection of the way. All countries will take credit consumption as the right of consumers to accept credit supply and return in a certain period. Thus, the law should recognize the credit rights of the consumer, and then expand the credit consumer rights, limit or strengthen the new obligations of the credit granting. If the credit granting in terms of credit exist discriminating consumers phenomenon, 
at present consumers can only according to the provisions of the law on the protection of rights and interests of consumers in China, requiring banks to stop infringement, elimination of influence, apology, and compensate for the losses. Equal access to credit and credit opportunities are the necessary conditions for the consumer to carry out credit consumption, credit consumer protection law should be clearly defined as an important right of credit consumers. In addition, the procedure is essential, the legislation should be provided, if the application is rejected, the credit applicant has the right to know the reasons for the refusal and the remedy.

\section{Acknowledgements}

The work of this paper is supported by Suzhou University outstanding academic and technical backbone project (Grant No. 2014XJGG14).

\section{References}

[1] E.H.Sinem, and Z.Kabaday1, "Innovation Orientation, Market Orientation and e-Loyalty: Evidence from Turkish e-Commerce Customers", Procedia - Social and Behavioral Sciences, Vol.99, (2013), pp.509-516.

[2] S.Manjit, and V.Kristine, "Social Commerce: A Contingency Framework for Assessing Marketing Potential",Journal of Interactive Marketing, Vol.27, (2013), pp.311-323.

[3] K.Grant and D.Edgar, "Risky business: Perceptions of e-business risk by UK small and medium sized enterprises (SMEs)," International Journal of Information Management, Vol.34, No.2, (2014), pp. 99-122.

[4] M.Savrul, "The Potential of E-commerce for SMEs in a Globalizing Business Environment", Procedia Social and Behavioral Sciences, Vol.150, (2014), pp.35-45

[5] S.Deniss, "Impact of e-environment on SMEs Business Development",Procedia - Social and Behavioral Sciences, Vol.156, (2014), pp.409-413

[6] M.Shoki, L.Yun, and N.Zakuan, "Examining Dimensions of Electronic Service Quality for Internet Banking Services",Procedia - Social and Behavioral Sciences, Vol.65, (2012), pp.854-859.

[7] S.Djelassi, and I.Decoopman, "Customers' participation in product development through crowd sourcing: Issues and implications”, Industrial Marketing Management, Vol.42, No.5, (2013), pp.683-692.

[8] H.Gebauer, M.Paiola, and B.Edvardsson, "A capability perspective on service business development in small and medium-sized suppliers", Scandinavian Journal of Management, Vol.28, No.4, (2012), pp.321-339.

[9] I.Janita, W.Chong, "Barriers of B2B e-Business Adoption in Indonesian SMEs: A Literature Analysis “,Procedia Computer Science, Vol.17, (2013), pp.571-578.

[10] A.D. Zaridis, and T. Dimosthenis, "Entrepreneurship and SME's Organizational Structure. Elements of a Successful Business", Procedia - Social and Behavioral Sciences, Vol.148, (2014), pp.463-467. 